\title{
+ 100: Old Age and New Photography
}

"Until very recently the contrast between the visible signs of ageing and the absence of their representations in visual culture was striking”, Anca Cristofovici writes in Touching Surfaces: Photographic Aesthetics, Temporality, Ageing (2009, 2). This situation has changed somewhat since then, although there still is a considerable lack of such representations in our society. In this essay, I discuss three projects by a new generation of photographers who negotiate the topics of ageing and old age from different perspectives. The photographers in question are recent graduates of a two-year masterclass at the Ostkreuzschule für Fotografie in Berlin. Under the guidance of Ute Mahler (photographer and co-founder of the Ostkreuz agency) and Ingo Taubhorn (curator of the Haus der Photographie, Deichtorhallen Hamburg), fourteen photographers work side by side to develop their own projects. In February 2020, the results were exhibited in the Kunstquartier Bethanien in Berlin under the title "True Stories_". The fourteen projects could not be more diverse, including portrayals of everyday life in a small village next to a nuclear power plant (800 Meter Tief by Nina Hansch), excavations of the photographer's own archive (Prelight Days by Attila Hartwig), and a quest for identity and belonging as the child of a migrant worker in the GDR (Garcias Tochter by Alina Simmelbauer). However, three of the projects are connected by the theme of old age and ageing. The photographs by Heidi Krautwald, Magdalena Stengel, and Natalya Reznik each deal with different aspects of ageing, and its implications for us as individuals and social beings.

\section{New Perspectives on Centenarians}

Plus minus hundred $( \pm 100)$ is the title of Magdalena Stengel's series of photographs, representing both the approximate age of its protagonists and the overarching theme of the series. Over two years, Stengel $\left({ }^{\star} 1987\right)^{2}$ researched and documented centenarians (and those who were about to become centenarians) across Germany. Stengel explains: "They somehow found me. I contacted local

1 The exhibition in Berlin was on display from February 15-23, and was supposed to travel, in a slightly reduced version, to Hamburg in April 2020. Given the current situation, with a global pandemic in place and a general halt to cultural and social activities, it remains questionable if and when it can be shown again.

2 https://www.magdalenastengel.com/about (March 10, 2020).

Ә OpenAccess. () 2021 Hanna Baro, published by De Gruyter. (cc) BY-NC-ND This work is licensed under the Creative Commons Attribution-NonCommercial-NoDerivatives 4.0 International License.

https://doi.org/10.1515/9783110683042-009 
newspapers and asked them whether they could write a very brief introduction about me and my project and that I am looking for centenarians. Afterwards, I simply waited and was contacted by them either directly or via their relatives". ${ }^{3}$ Stengel then visited several of her new contacts, spending hours with them and getting a glimpse into their lives - their present lives and the lives already lived. Her work not only depicts old people, but also opens a window onto their personality, leaving space for interpretation. The series does not give an exhaustive, complete picture of old age in general, but instead offers glimpses into very personal examples of old age. In one of Stengel's photographs, chosen for the cover of the exhibition invitation, an elderly man is seen peeking through a thick, orange velvet curtain which covers the entire image (fig. 1). He uses his left hand to draw back the curtain a crack, partially revealing his laughing face. He seems happy. For the moment. Taking a closer look at him, or the parts of him that can be seen, we notice an odd object around his wrist. For most viewers, the detail would be easily overlooked at first sight. Once seen, however, it cannot be unseen - and, for most people who have elderly family members, a new layer of the story starts to unfold. The wristband with its distinctive red button is an emergency alarm, worn by many elderly people who still live by themselves. The button is directly connected to the welfare organization which has provided it. When pressed - if the person fell down, feels sick, or is otherwise in distress a member of the organisation immediately replies and, together with the elderly person, decides whether to send an ambulance or any other help. The service is available $24 / 7$, every day of the year, and enables many elderly people to stay in their own homes and maintain a degree of independence. Having discovered this wristband, we can infer that its owner - the laughing man behind the curtain probably still lives on his own, despite his age. Is this perhaps a reason for his happiness?

Compared to other photographs depicting centenarians - apparently in great demand these days - Stengel's do not show only their faces, but try to capture their subjects' personality. ${ }^{4}$ This leads both to happy images - showing, for example, a centenarian surrounded by his large family at his hundredth birthday party (fig. 2) - and ones in which a certain sadness resonates, as in the image of a 98-year-old woman standing in front of a sewing table (fig. 3). Stengel explains that the woman still has to take on occasional sewing jobs, as her pension is too small to live on. In addition to the photographs, \pm 100 consists of three short

3 Interview with Magdalena Stengel from February 15, 2020.

4 See for example the series by Karsten Thormaehlen where he photographed centenarians all over the world, published in Karsten Thormaehlen, 100 Jahre Lebensglück: Weisheit, Liebe, Lachen (Munich: Knesebeck, 2017). 


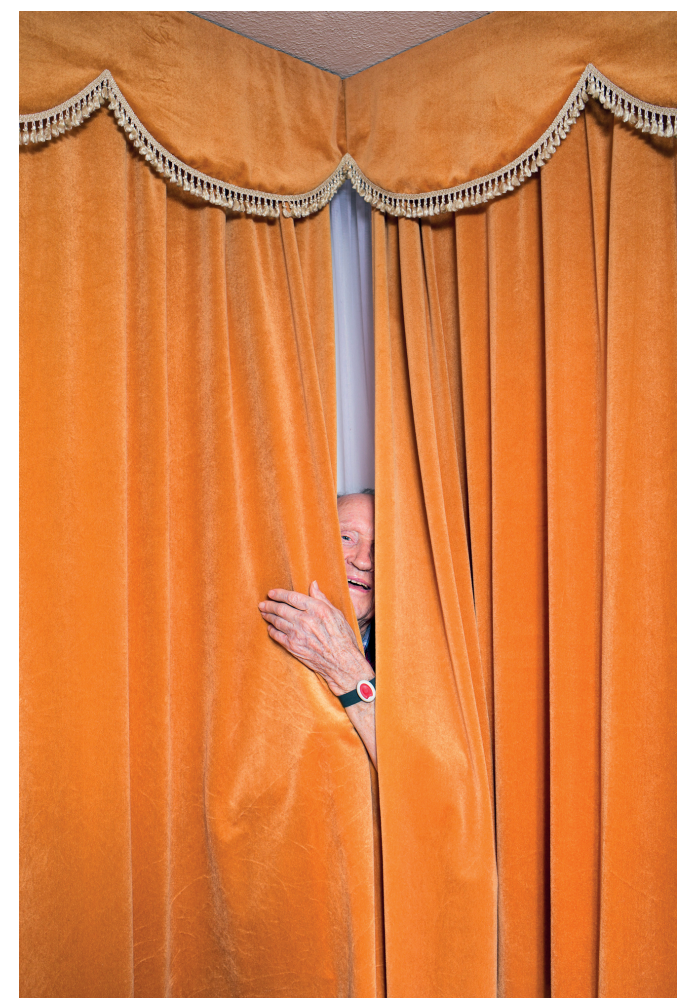

Figure 1: Magdalena Stengel, \pm 100 , carbon print, $42 \times 29,7 \mathrm{~cm}, 2019$ (C) Magdalena Stengel

videos of three of the people photographed. One shows a man dancing; another shows a man playing the harmonica; in the third, we see a man's hand holding a bouquet of artificial flowers upside down, turning them slowly in his fingers. The artist notes that the bouquet was made by his deceased wife, and that it stands in for her in the video. Rather than a portrait of the husband, this is a portrait of the wife's absence.

\section{"The photograph tells me the death in the future"}

While Stengel's photographs are about their lives, there is always another topic present within this celebration. The thought of the end of these lives lurks be- 


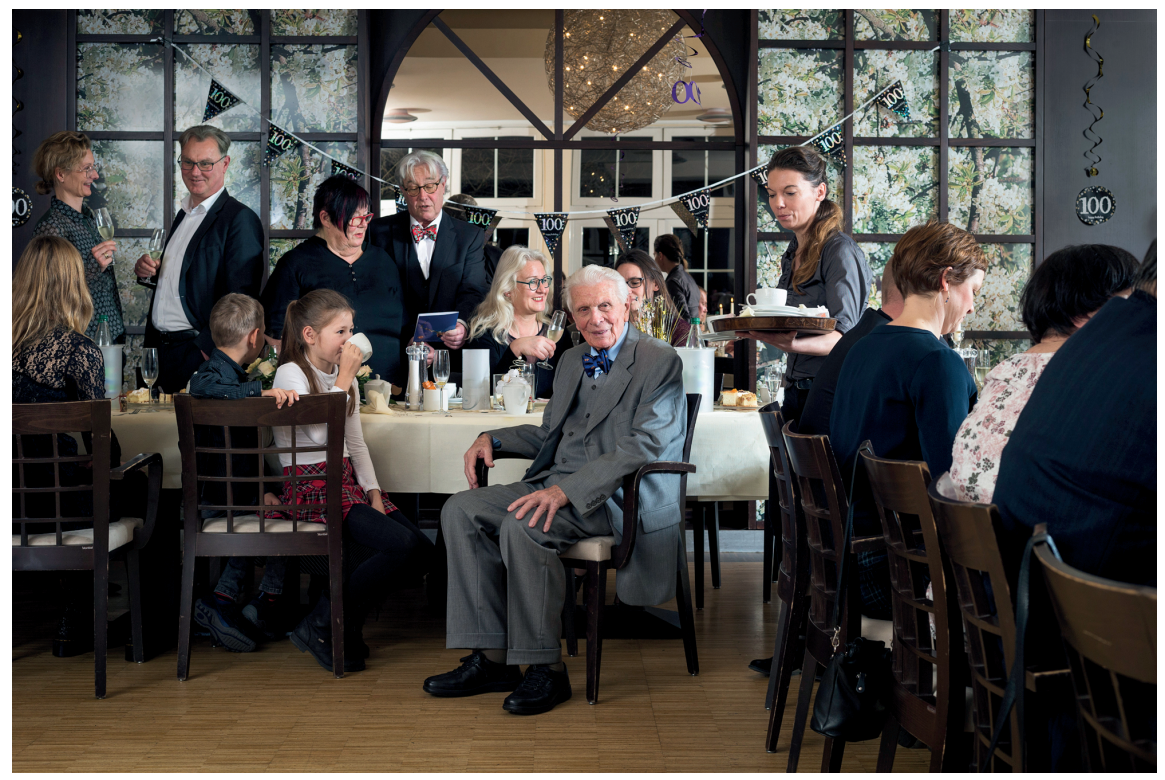

Figure 2: Magdalena Stengel, \pm 100 , carbon print, $42 \times 29,7 \mathrm{~cm}, 2019$ (C) Magdalena Stengel

neath the photographs - or, as Roland Barthes puts it in Camera Lucida: "Photography is a kind of primitive theater, a kind of Tableau vivant, a figuration of the motionless and made-up face beneath which we see the dead" $(1981,32){ }^{5}$ Looking at the photograph of a young man in his prison cell, waiting to be hanged, he writes: "But the punctum is: he is going to die. I read at the same time: This will be and this has been; I observe with horror an anterior future of which death is the stake. By giving me the absolute past of the pose (aorist), the photograph tells me death in the future. ... Whether or not the subject is already dead, every photograph is this catastrophe" (Barthes 1981, 96). For Barthes, the punctum of a photograph is the spontaneous, affective moment when a small, often random detail catches the viewer's interest and draws their attention closer to the image and the story behind it. Looking again at Stengel's photograph of the laughing old man behind the curtain, the emergency but-

5 For more studies on photography and death, see the seminal study by Katharina Sykora, Die Tode der Fotografie, Vol. 1: Totenfotografie und ihr sozialer Gebrauch (Munich: Fink, 2009), and Vol. 2: Tod, Theorie und Fotokunst (Munich: Wilhelm Fink, 2015). For a study on Sontag, photography, and death, see Matthias Christen, “All Photographs are Memento Mori: Susan Sontag und der Tod in der Fototheorie”, Fotogeschichte 32.126 (2012): 23-36. 


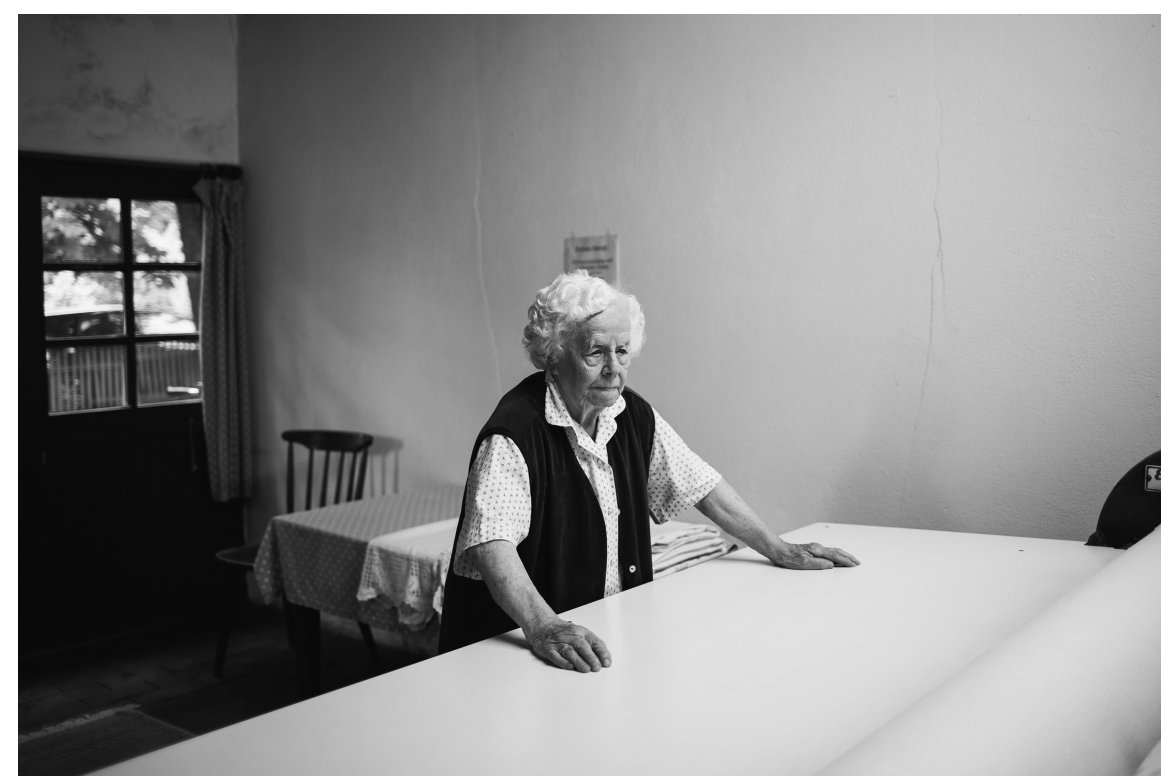

Figure 3: Magdalena Stengel, \pm 100 , carbon print, $42 \times 29,7 \mathrm{~cm}, 2019$

(c) Magdalena Stengel

ton around his wrist becomes the punctum. Given that the people portrayed by Stengel are, or are approaching, a hundred years old, it cannot be denied that their lives are coming to an end. They are already years beyond the average life expectancy in Germany. This reality sets in when Stengel received a message, during the exhibition opening, that one of the women she photographed had died, the day after her hundredth birthday. For the woman, the anterior future has become the present and her photograph instantly becomes a memento mori, a past that no longer exists.

\section{A 'Greynaissance' in The Old World}

Natalya Reznik's ( $\left.{ }^{\star} 1981\right)$ series, The Old World, offers a contrast to Stengel's depiction of old age. ${ }^{6}$ The title does not refer to a bygone world, but to an imagined future world where people become older and older, changing society. Reznik tries to imagine a future of increasing numbers of fit, energetic elderly people,

6 The Old World consists of eight photographs so far, but is an ongoing project. 
taking an active role in society. Her view of this scenario is positive, something that resonates in her work. Here, photography is not a window onto the past, but the future. Beautiful elderly women pose gracefully. In the blurred backgrounds, we sense cities and their skylines (fig. 4), or a view of a natural landscape by the

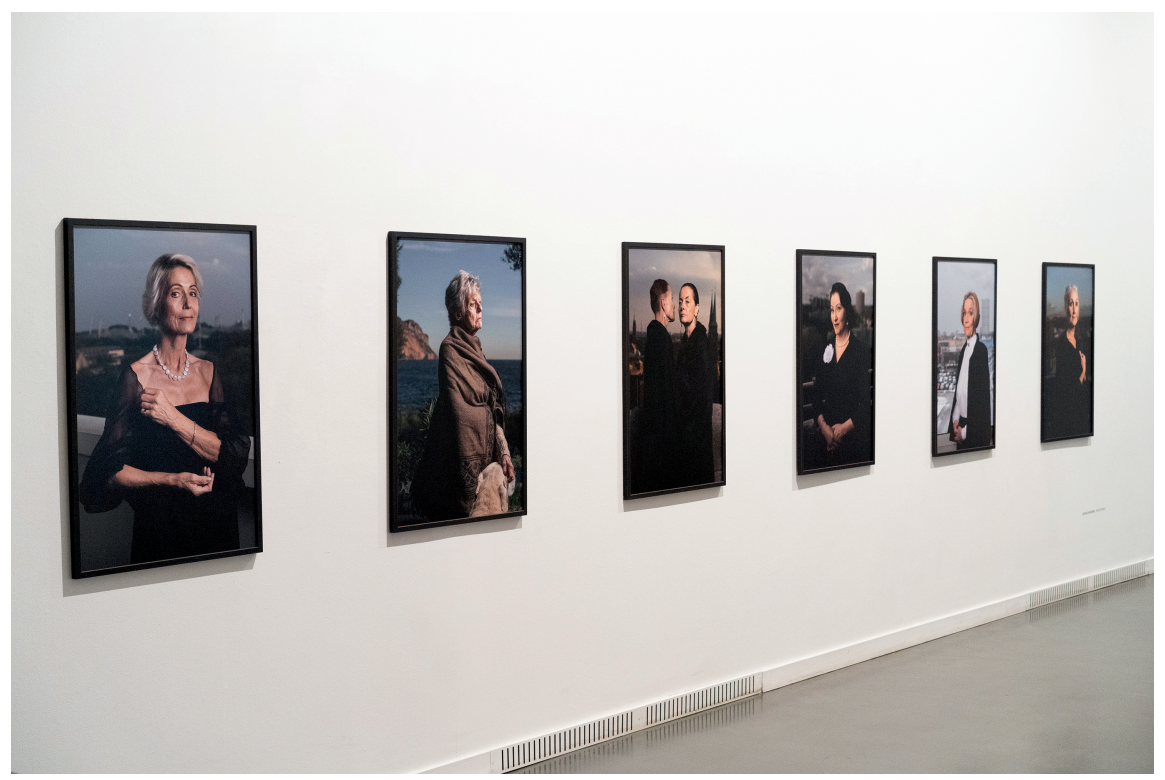

Figure 4: Natalya Reznik, The Old World, 2017-2019 (installation view, Kunstquartier Bethanien, Berlin 2020)

(c) Natalya Reznik 2020

sea. Only the subtitles reveal where these women were photographed, and where they likely live. Reznik chooses balconies and terraces as settings for her portraits, alluding to such places' character, which oscillates between private and public: both part of its owner's private environment (the house or apartment), and of the public sphere where people passing by can see you. The balcony is neither completely private nor completely public, but includes both worlds.

The Old World recalls idealised female portraits from the Renaissance, where the sitters were depicted using symbols like jewelry or clothing that referred to their social status within early modern society. ${ }^{7}$ Then and now, both gender

7 For an elaborate overview of female Renaissance portraits and their cultural and social constructions, see David Alan Brown, Virtue and Beauty: Leonardo's Ginevra de' Benci and Renais- 
and age are social constructs, rather than given biological categories, and this understanding permeates Reznik's project. Like Renaissance portraits, The Old World shows most of these women in half-length and three-quarter profile. Each wears elegant black robes, their hair done, make-up partially hiding their wrinkles (fig. 5). While the portraits are staged, they were not re-touched.

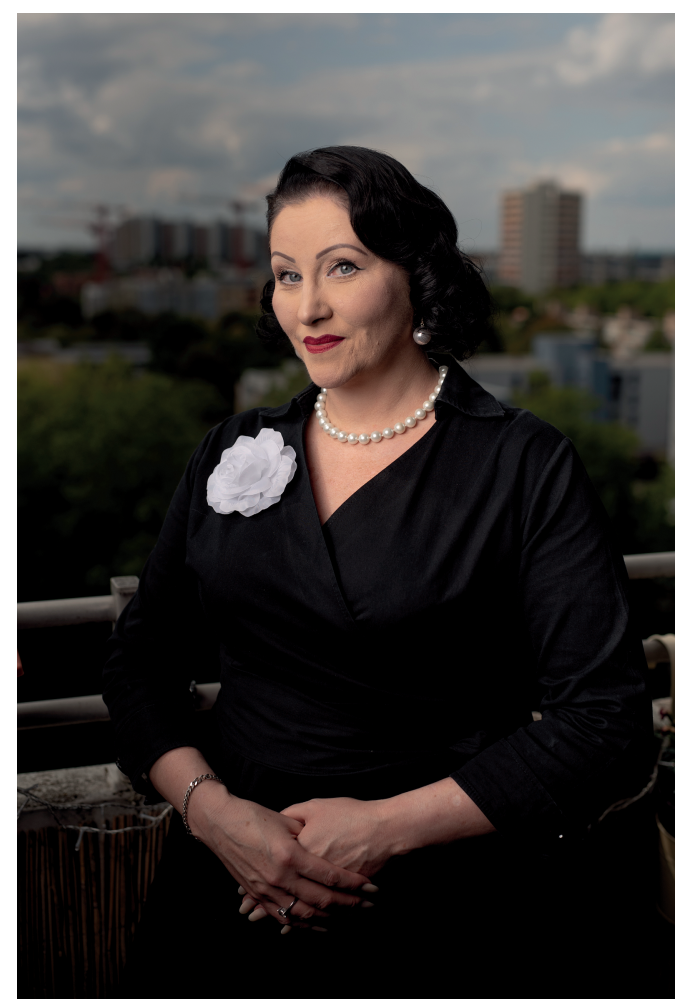

Figure 5: Natalya Reznik, The Old World (Hexana), Munich, Germany, carbon print, 67 x 100 $\mathrm{cm}, 2018$

(C) Natalya Reznik

sance Portraits of Women (Princeton: Princeton University Press, 2001), and Paola Tingali, Women in Renaissance Art: Gender, Representation, Identity (Manchester and New York: Manchester University Press, 1997). 
Reznik explains that some of her sitters asked to have certain wrinkles eliminated in post-production, but that she refused, since she wanted to show these women as they are. ${ }^{8}$

"The Greynaissance starts here", writes Reznik in her short description of The Old World (Reznik 2020). "Greynaissance" is a term coming from social media, used to describe beautiful elderly models, mostly women over the age of fifty or sixty, some of whom are featured in The Old World. Instagram contains numerous images of these models under the hashtag '\#greynaissance'. The beauty standards at work, however, are just the same as for younger models: all of them are tall and slim, with high cheek bones and delicate features. Only their silver hair and wrinkles differentiate them from the younger models that have dominated the media for so long. There is no diversity in the 'Greynaissance'. Even though the women in The Old World have aged chronologically (they are fifty- and sixty-plus), their biological, social, and cultural age seem far younger. ${ }^{9}$ Wrinkles aside, they do not seem to have aged much, and are still presented as strong, youthful women. Socially and culturally, they do not fit the category of "old women": they might have retired from their previous jobs, but have now become models or social media influencers, with thousands of followers on Instagram and other platforms. One of the most famous examples of these models is the American Iris Apfel, still a fashion icon at the age of 98. In 2005, The Metropolitan Museum of Art devoted an entire exhibition to her, Rara Avis: Selections from the Iris Apfel Collection. ${ }^{10}$ While this positive outlook on old age and increasing representations of it in media is good, Greynaissance women like Apfel remain the exception rather than the rule. We wonder where the fragile, non-eccentric, vulnerable, lonely aspects of old age - which affect a large part of elderly men and women - are represented, and why they remain largely invisible in our visual culture. Despite the positive representation of old age in visual culture and media, we must remember that this is social media, where image and identity are highly curated and staged.

8 Interview with Natalya Reznik, February 15, 2020.

9 Cf. Kathleen Woodward's distinction between chronological, biological, social, and cultural age in "Performing Age, Performing Gender", National Women's Studies Association Journal (NWSA) 1.1 (2006): 163.

10 https://www.metmuseum.org/press/exhibitions/2005/rara-avis-selections-from-the-irisapfel-collection (March 10, 2020). 


\section{The Other Side of the Coin: Hope and Vulnerability}

In another project dealing with ageing and old age, Reznik works in a completely different pictorial language. The way she portrays her grandmother in Hope (2011-2019) could not be more different to her method of presenting the beautifully dressed and groomed women of The Old World. Nadezhda, Reznik's nonagenarian grandmother, is shown in her everyday outfit at home in Perm, Russia, without make-up, no styled hair (fig. 6). The pictures resemble spontaneous

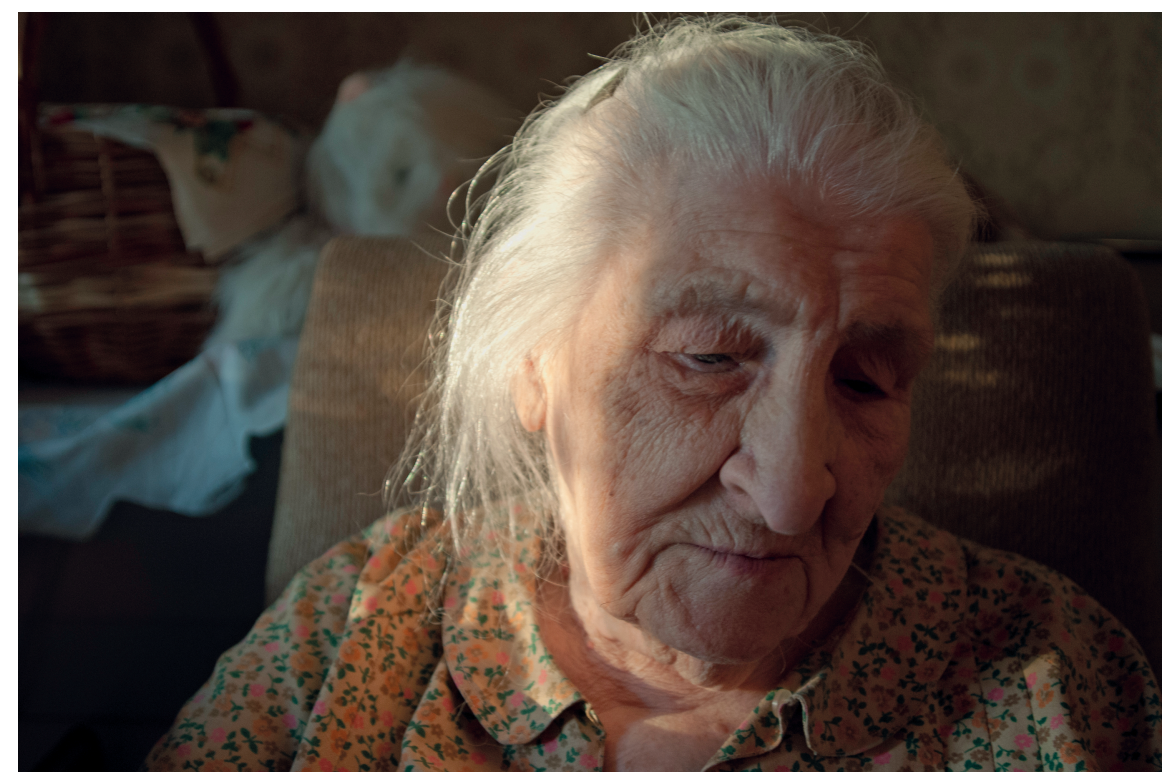

Figure 6: Natalya Reznik, Hope, 2011-2019

(C) Natalya Reznik

snapshots of the everyday life of an old woman who cannot live alone anymore, requiring help from her family, and especially from her own daughter, Reznik's mother (fig 7). There is a vulnerability in these images, underlined in the text accompanying the project:

She feels disgust towards her changed physiology, infirm body and illnesses. She has desire to love and to be loved - and at the same time she feels being unworthy of it. She constantly feels being offended because she thinks that people have the laugh of her, because of her 
weakness (doesn't hear properly, almost blind). Sometimes she tells that she hates herself. She stays at home all the time (old house, no elevator). Sometimes she is angry and tells my mother and me: “You don't give me keys, I can't go outside!". But in fact she knows that she can’t go alone without us because of her health. (Reznik 2011)

We become aware of Nadezhda's struggle, as an old woman who dislikes her ageing body and her failing health, which make her dependent on others. She feels trapped, in her house and her body.

Reznik's two projects could not be more different, and show two quite different aspects of female ageing. The Old World depicts an utopian process of ageing, where women are still defined by their beauty. Hope, by contrast, is an honest, sometimes harsh portrayal of the social, psychological, and physical effects of age: loneliness, immobility, dependency, sickness, and shame. Is there a 'double standard of ageing', as Susan Sontag (1972) wrote in her famous essay - not only between men and women, but also between women themselves?

Hope recalls work by other artists, like Phillip Toledano's series Days With My Father, which Reznik has written a brief essay about (2013). ${ }^{11}$ After his mother's sudden death in 2006, Toledano began to take pictures of his elderly father, who suffers from short-term memory loss, as "an ongoing record of my father, and of our relationship. For whatever days we have left together" (2006). Toledano's father cannot remember that his wife has died, or that he attended her funeral. Toledano describes the unbearable situation: "After a while, I realised I couldn't keep telling him that his wife had died. He didn't remember, and it was killing both of us, to re-live her death constantly. I decided to tell him she'd gone to Paris, to take care of her brother, who was sick. And that's where she is now" (2006).

Memory - or, rather, the loss of it - is at the core of Hope. In Russian, 'Nadezhda' means 'hope'. The series is therefore titled Hope, as is an accompanying photobook containing selected images of her grandmother, who suffers from Alzheimer's. Reznik stitched together each of the fifteen photobooks by hand. Using red thread to gather these photographs of her vanishing grandmother, Reznik pays tribute to the fact that Nadezhda "used to sew clothes for herself and her children in Soviet times, when there were shortages in the stores" (2019). Furthermore, as both an artist and Nadezhda's grandchild, Reznik "literally stitched the

11 Born in Russia and now living and working in Germany, Reznik is an artist and photographer, holds a $\mathrm{PhD}$ in philosophy of culture from St. Petersburg State University, and writes about photography and ageing. 
pieces of memory for her together in the photo book" (2019). ${ }^{12}$ Stitching and sewing are typically associated with women's work, recalling artists like Annegret Soltau, who used needle and thread to stitch together photographs of the bodies of four generations of women: her own, her daughter's, her mother's, and her grandmother's (Generativ - Selbst mit Tochter, Mutter und Großmutter, 19942005). Photographs become corporeal collages of different generations. The photographic tradition of portraying one's elderly parents as a form of coping with their ageing process can already be seen in works by Richard Avedon (1993) and Nan Goldin (Jenkins 2003), among others. Photography is not the only medium for documenting and reflecting upon the relationship between the elderly, their grown-up children, and inevitable loss. In pas pu saisir la mort (Impossible to Catch Death) (2007), the French artist Sophie Calle filmed her dying mother over many days and hours. An edited eleven-minute version of this private observation at her mother's death bed was shown at the Venice Biennale in 2007. Asked why she chose to record such intimate, private moments, Calle replied: "I just wanted to film her death because I feared not being there at the very last moment, or missing a final word from her to me. Apparently people always choose to die the minute you look away, so I wanted to be there" (Pfeiffer 2010). Filming the process of dying and the moment of death is one way to cope with such existential loss. In Une mort très douce (A Very Easy Death) (1985), Simone de Beauvoir uses the written word to come to terms with her mother's death in 1963. Writing a year later, Beauvoir meticulously recounted the process of death in a Parisian hospital. It is a powerful account of a loved one's last days, as well as an honest, extremely personal reflection of a complicated relationship during its final six weeks.

\section{Performing Age, Performing Gender}

The theme of generation runs through Heidi Krautwald's ( ${ }^{\star 1960)}$ work, although her photographs speak a slightly different language. The topic of ageing is not as strongly present as in \pm 100 or The Old World and Hope. Instead, In der Zwischenzeit (In the Meantime) negotiates questions of identity, Krautwald's role as a woman, and the complex, simultaneous role of daughter, mother, and wife.

12 'My grandmother's name, Nadezhda, means 'hope' in Russian. She has been always interested in fashion. She used to sew clothes for herself and her children in Soviet times, when there were shortages in the stores. Now she is 94 , blind, and has almost lost her memory due to Alzheimer's, but still keeps hoping to be able to sew again. I literally stitched the pieces of memory for her together in the photo book 'Hope'.” (Reznik 2019) 


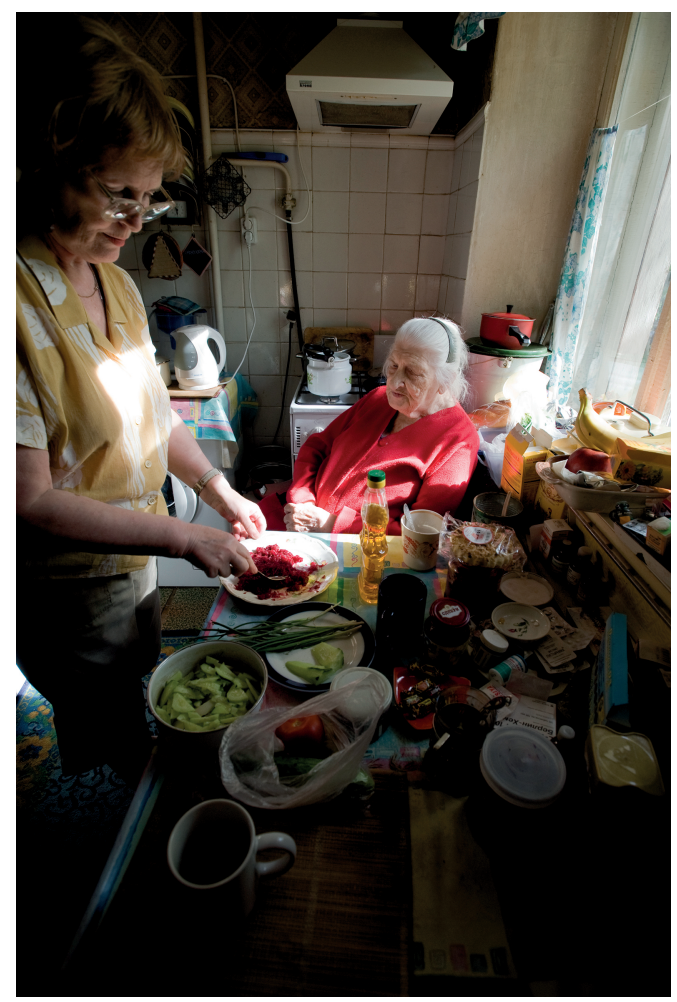

Figure 7: Natalya Reznik, Hope, 2011-2019

(C) Natalya Reznik

Krautwald began taking photographs of herself in 1982, after her first child was born. She used the self-portrait as her artistic language between 1982 and 1993, when she stopped to concentrate on other ways of photography. She returned to the self-portraits for the Meisterklasse in 2018. ${ }^{13}$ In der Zwischenzeit (fig. 8) consists of several photographs, taken between 1982 and the present day and is accompanied by a photobook..$^{14}$ By combining early photographs with later ones, ageing and the passage of time in general become evident. Looking at the juxta-

13 Interview with Heidi Krautwald on February 15, 2020.

14 On display at the exhibition wall were fifteen digital photographs $(30 \times 45 \mathrm{~cm})$ and six blackand-white analog photographs $(20$ x $30 \mathrm{~cm}$ ) (https://www.heidikrautwald.de/projekte/20162020/in-der-zwischenzeit/). The photobook consists of eighteen analog black and white photographs and ninety-eight digital photographs. There are no titles for any of the photographs, but an index within the photobook reveals the date and place where they were taken. 


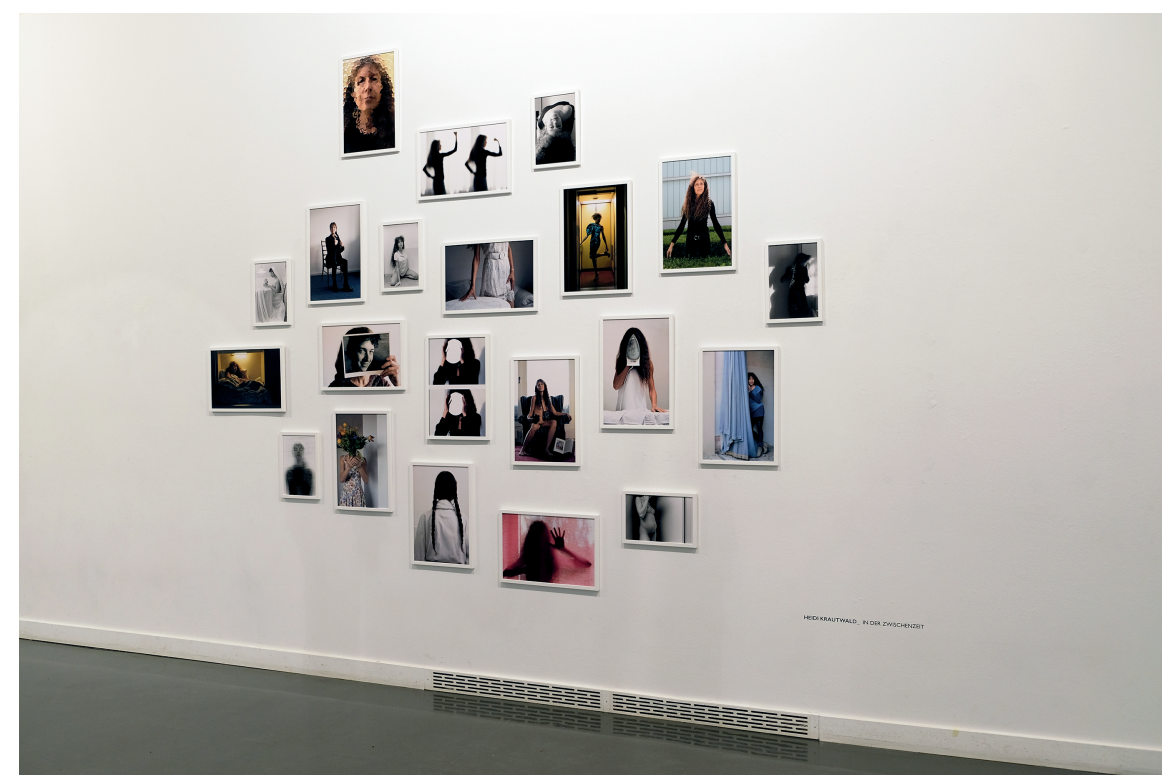

Figure 8: Heidi Krautwald, In der Zwischenzeit, 1982-2019 (installation view, Kunstquartier Bethanien, Berlin 2020)

(c) Heidi Krautwald

position of her self-portraits as a young woman and a new mother in her early twenties (fig. 9) with works that show her as a mature woman in her fifties (fig. 10), we necessarily think of the time between those two moments, and of the experiences of the woman in the picture. Seeing two photographies of Krautwald, we imagine the time between them - the unseen time that has passed from one moment to the other. Her work shows ageing more subtly than Stengel and Reznik do. Krautwald joins a photographic tradition of work, by artists like Roman Opalka and Nicholas Nixon, which uses the time in between photographs of the same people at different stages in their life. ${ }^{15}$ Opalka's photographic section of his lifelong project $1965 / 1-\infty$ is meticulously executed, like everything else in the work, with each photograph showing the face of the artist in exactly the same position, with the same facial expression. Only by looking at several photographs alongside each other can we see the ageing process reflected in

15 For a brief but excellent analysis of these two series, and especially temporality and the ageing face, see Sabine Kampmann, Bilder des Alterns: Greise Körper in Kunst und visueller Kultur (Berlin: Reimer, 2020), 130-135. 


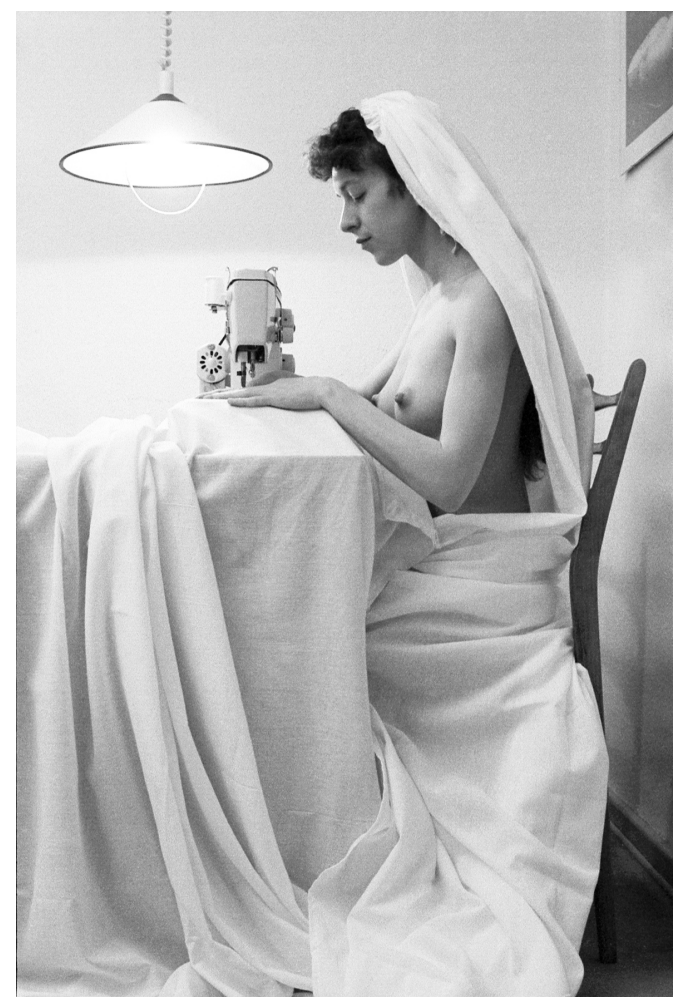

Figure 9: Heidi Krautwald, In der Zwischenzeit, 20 x 30 cm, 1989 (C) Heidi Krautwald

his face. In Nixon's series The Brown Sisters, the time span between each image is much longer. Nixon photographed his wife and her three sisters every year when the family gathered. We see how time has changed their faces, their bodies, and the fashion they wear over more than forty years.

In the photobook accompanying In der Zwischenzeit, Krautwald includes images in which she poses with her children, representing herself as a mother. In her other works, however, we only see the artist herself. Sometimes she stages herself recreating the settings and poses of well-known self-portraits by artists like Frida Kahlo, facing the camera and the viewer directly. In others, she covers her face, either with a bouquet of flowers, an ironing board, a mirror, or an older photograph of herself. Some photographs show Krautwald's nude body, both younger (fig. 11) and older (fig. 12). By including portraits in which her naked body is the main focus, and which enable a direct juxtaposition between her young and old body, Krautwald makes a subtle statement about the ageing fe- 


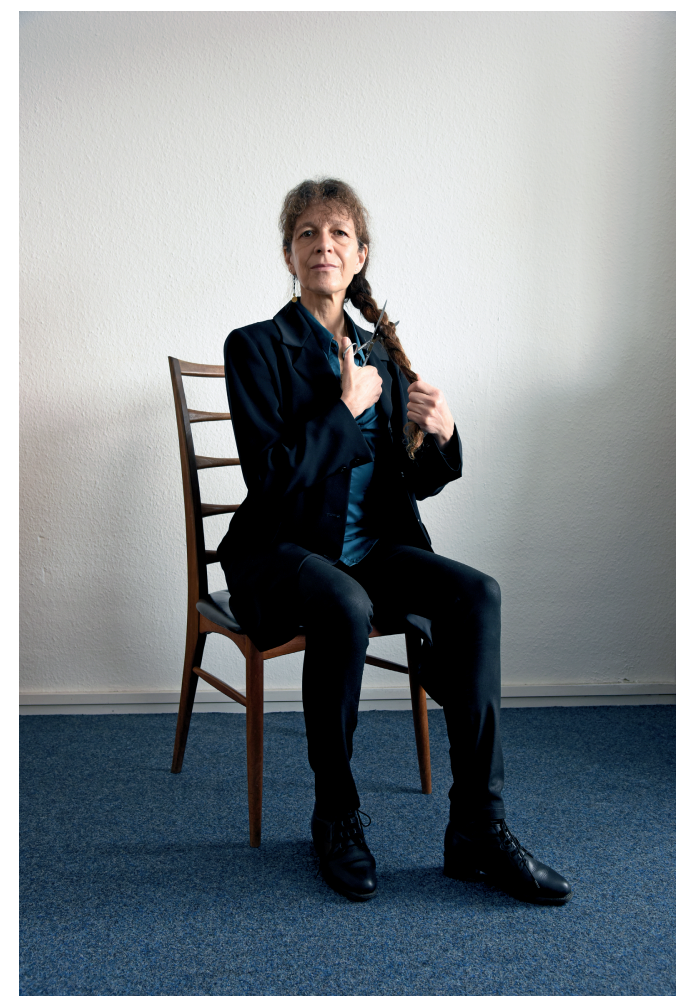

Figure 10: Heidi Krautwald, In der Zwischenzeit, 30 x 45 cm, 2019 (C) Heidi Krautwald

male body and its sexuality - a topic which is still to some degree invisible in our society. As Kathleen Woodward writes, "the body has been the locus of attention for many years, but the older female body has been significant only in terms of its absence" (2006, 162). In Krautwald's work, the ageing body is present, visible despite the youthfulness of her later self-portraits. The passage of time and the process of ageing materialise in the ageing body (Hülsen-Esch et al. 2013, 25).

Though Krautwald's appearance, poses, and body change over time, one aspect is consistent throughout: her long, curly hair. Time has no effect on Krautwald's hair: it does not go grey, apparently, and her hair style does not change over the years. This is in stark contrast to her body. Does the artist cling to her long hair as a timeless token of female beauty? ${ }^{16}$

16 Hair has a complex and fascinating history in the visual arts and culture. For a study on hair 


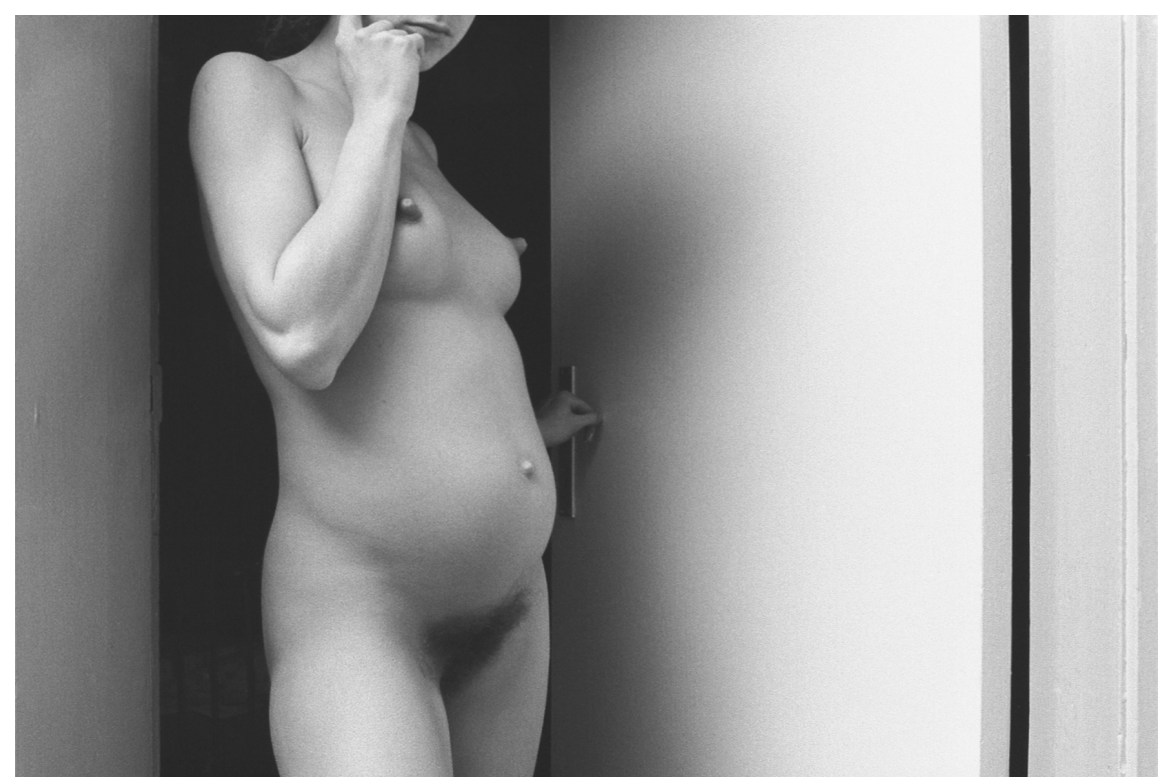

Figure 11: Heidi Krautwald, In der Zwischenzeit, 20 x 30 cm, 1987

(c) Heidi Krautwald

\section{"Time's relentless melt"}

The three artists discussed here offer three quite different perspectives on ageing and its representation in photography. Stengel's work provides a poetic document of old age through the personal history of male and female centenarians, with vitality and autonomy playing an important role. Reznik presents us with two scenarios of old age: one optimistic, focused on a utopian world in which ageing is associated with beauty, good health, grace, and activity, and the other - much more personal - confronting the viewer with the opposite. Hope documents the decline of her grandmother, who struggles with all the aspects of old age neglected in The Old World: failing health, memory loss, loss of identity, loneliness, dependency, frustration and sadness. Krautwald's In der Zwischenzeit adds yet another layer, focusing on the changing role of a woman throughout time: from a daughter and young girl to a wife and lover, finally start-

and its cultural implications in art and theory of the fifteenth and sixteenth century, for example, see Julia Saviello, Verlockungen: Haare in der Kunst der Frühen Neuzeit (Emsdetten and Berlin: Edition Imorde, 2017). 


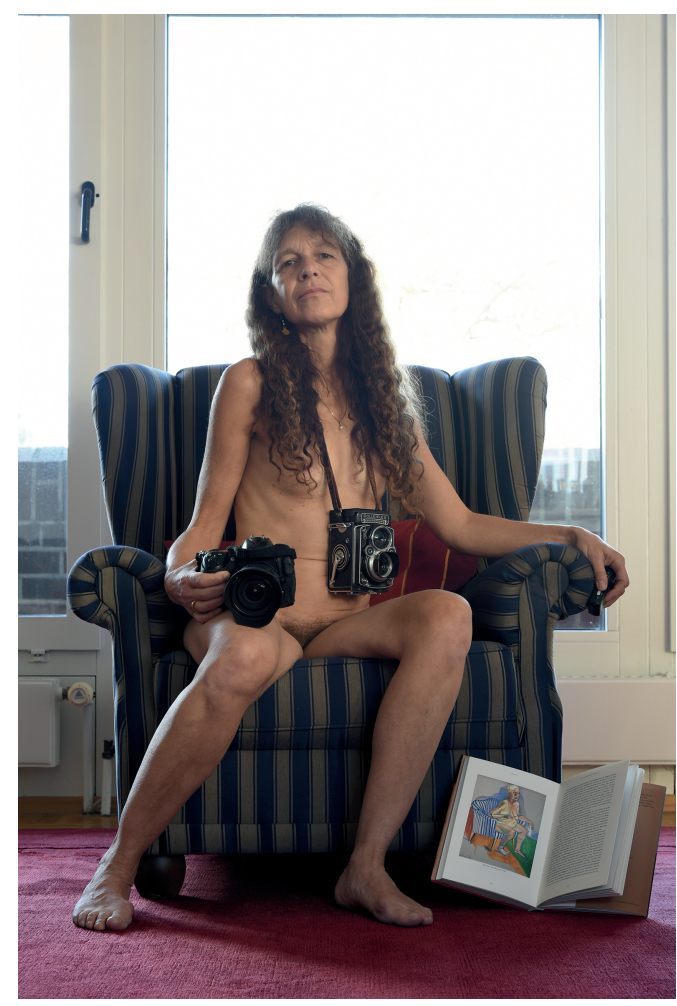

Figure 12: Heidi Krautwald, In der Zwischenzeit, 30 x 45 cm, 2018 (C) Heidi Krautwald

ing a family herself. Not only age but gender are performed. ${ }^{17}$ All three artists offer a female perspective on ageing. Stengel focuses on both men and women, while Reznik and Krautwald look at different representation of women and ageing in our society. The three artists also cover a broad spectrum of ages: from extreme old age (Stengel) to middle age (Reznik in The Old World) to young and middle age, as well as the time span in between those two life stages (Krautwald). Even though their projects differ, the majority of the works discussed here are a sort of "memento mori", as Susan Sontag describes it: "All photographs are memento mori. To take a photograph is to participate in another person's (or thing's) mortality, vulnerability, mutability. Precisely by slicing

17 Cf. Kathleen Woodward. "Performing Age, Performing Gender”, National Women's Studies Association Journal (NWSA) 1.1 (2006): 162-189. 
out thus moment and freezing it, all photographs testify to time's relentless melt” $(1977,14)$.

Mortality, vulnerability and mutability - especially among the elderly - are more present than ever in the current health crisis. COVID-19 has revealed the vulnerability of the elderly in ways we have managed to forget, despite all the research that has been done into ageing, and despite the increased visibility and appreciation of elderly people in our society. ${ }^{18}$

\section{Works cited}

Avedon, Richard. An Autobiography. New York: Random House, 1993.

Barthes, Roland. Camera Lucida: Reflections on Photography (translated by Richard Howard).

New York: Farrar Straus \& Giroux, 1981.

Beauvoir, Simone de. A very Easy Death. New York: Pantheon, 1985.

The British Society of Gerontology. British Society of Gerontology Calls on Government to

Reject Policy Responses to COVID-19 Based Only on Chronological Age (Press release).

https://www.britishgerontology.org/DB/latest-news/press-release-from-british-society-ofgerontology-20-march-2020. 20 March 2020 (21 March 2020).

Brown, David Alan. Virtue and Beauty: Leonardo's Ginevra de' Benci and Renaissance

Portraits of Women (exh. cat.). Princeton: Princeton University Press, 2001.

Christen, Matthias. "All Photographs are Memento Mori: Susan Sontag und der Tod in der

Fototheorie." Fotogeschichte 32.126 (2012): 23-36.

Cristofovici, Anca. Touching Surfaces: Photographic Aesthetics, Temporality, Aging. New York and Amsterdam: Rodopi, 2009.

Jenkinson, John. Ed. The Devil’s Playground: Nan Goldin. London: Phaidon, 2003.

18 The British Society of Gerontology issued a press release on March 20, 2020, "call[ing] on Government to reject policy responses to COVID-19 based only on chronological age". Their first key point addresses exactly the ageist and stereotypical view of elderly people that still plays a crucial part in our society: "It is wrong and overly simplistic to regard people aged 70 and above as being vulnerable, a burden, or presenting risks to other people. Many people in this age group are fit, well, and playing an active role in society. Older people participate in paid work, run businesses, volunteer, are active in civil society and the cultural life of communities, and take care of family members including parents, spouses/partners, adult children (especially those living with disabilities), and grandchildren.” Furthermore, the Society "expresses its objection to any policy which differentiates the population by application of an arbitrary chronological age in restricting people's rights and freedoms. While people at all ages can be vulnerable to COVID-19, and all can spread the disease, not all people over the age of 70 are vulnerable, nor all those under 70 resilient. Given older adults' multiple social roles, quarantining the more than 8.5 million people over 70 years of age will deprive society of many people who are productive and active and who can be a key part of the solution by supporting the economy, families and communities". 
Kampmann, Sabine. Bilder des Alterns: Greise Körper in Kunst und visueller Kultur. Berlin: Reimer, 2020.

Krautwald, Heidi. In der Zwischenzeit. https://www.heidikrautwald.de/projekte/2016-2020/inder-zwischenzeit/. 1982-2019 (10 March 2020).

Pfeiffer, Alice. All About Her Mother: Sophie Calle. https://www.artnews.com/art-in-america/in terviews/sophie-calle-palais-de-tokyo-56160/. 2010 (10 March 2020).

Reznik, Natalya. Hope. https://www.reznikdavydov.com/projects/hope-2019/ https://www.reznikdavydov.com/projects/hope-2011/. 2011-2019 (10 March 2020).

Reznik, Natalya. Images of Elderly People in Contemporary Documentary Projects. http://vjic. org/vjic2/?page_id=2424. The VASA Journal of Images and Culture 3, 2013 (10 March 2020).

Reznik, Natalya. Hope (Photobook). https://www.reznikdavydov.com/projects/hope-2019/. 2019 (10 March 2020).

Reznik, Natalya. The Old World. https://www.truestories-oks.de/natalya-reznik. 2020 (10 March 2020).

Saviello, Julia. Verlockungen: Haare in der Kunst der Frühen Neuzeit. Emsdetten and Berlin: Edition Imorde, 2017.

Sontag, Susan. "The Double Standard of Aging." The Saturday Review September 23 (1972): $29-38$.

Sontag, Susan. On Photography. New York: Farrar Straus \& Giroux, 1977.

Stengel, Magdalena. https://www.magdalenastengel.com/about. (10 March 2020).

Sykora, Katharina. Totenfotografie und ihr sozialer Gebrauch (Die Tode der Fotografie Vol. 1). Munich: Wilhelm Fink, 2009.

Sykora, Katharina. Tod, Theorie und Fotokunst (Die Tode der Fotografie Vol. 2). Munich: Wilhelm Fink, 2015.

Tingali, Paola. Women in Renaissance Art: Gender, Representation, Identity. Manchester and New York: Manchester University Press, 1997.

Thormaehlen, Karsten. 100 Jahre Lebensglück: Weisheit, Liebe, Lachen. Munich: Knesebeck, 2017.

Toledano, Phillip. Days with My Father. http://mrtoledano.com/photo/days-with-my-father/. 2006 (10 March 2020).

von Hülsen-Esch, Andrea, Miriam Seidler, and Christian Tagsold. "Methoden der Alter(n) sforschung: Disziplinäre Positionen - transdisziplinäre Perspektive.” Methoden der Alter(n)sforschung: Disziplinäre Positionen und transdisziplinäre Perspektiven. Eds. Andrea von Hülsen-Esch, Miriam Seidler, and Christian Tagsold. Bielefeld: transcript, 2013. 7-33.

Woodward, Kathleen. “Performing Age, Performing Gender.” National Women's Studies Association Journal (NWSA) 1.1 (2006): 162-189. 
